\title{
Synthesis of boehmite powder from aluminum etching solution
}

\author{
Young-Soo Park, In-Hee Wui, Woo-Seok Cho, Jin-Ho Kim and Kwang-Taek Hwang ${ }^{\dagger}$ \\ Icheon Branch, Korea Institute of Ceramic Engineering and Technology, Icheon 467-843, Korea
}

(Received October 16, 2012)

(Revised November 2, 2012)

(Accepted November 16, 2012)

\begin{abstract}
Boehmite $(\mathrm{AlOOH})$ powder was synthesized using waste aluminium etching solution. In waste solution, precipitated phase was gibbsite $\left(\mathrm{Al}(\mathrm{OH})_{3}\right)$, and boehmite $(\mathrm{AlOOH})$ phase was obtained at $\mathrm{pH}$ of 7 and 8 controlled by addition of acid. Boehmite powder was obtained by washing process to remove the $\mathrm{Na}$ ion in precipitated solution. Mean particle size of obtained powder was $40 \mathrm{~nm}$. Boehmite phase transformed to $\alpha-\mathrm{Al}_{2} \mathrm{O}_{3}$ phase via $\gamma-\mathrm{Al}_{2} \mathrm{O}_{3}, \delta-\mathrm{Al}_{2} \mathrm{O}_{3}$, and $\theta-\mathrm{Al}_{2} \mathrm{O}_{3}$.
\end{abstract}

Key words Aluminum etching, Boehmite, Alumina, Precipitation

\section{알루미늄 에칭액으로부터 베마이트 분말 합성}

박영수, 위인희, 조우석, 김진호, 황광택

한국세라믹기술원, 이천분원, 467-843

(2012년 10월 16일 접수)

(2012년 11월 2일 심사완료)

(2012년 11월 16일 게재확정)

요 약 알루미늄 에칭 폐액으로부터 boehmite(AlOOH) 분말을 합성하였다. 폐액에서 침전되어 있는 결정상은 gibbsite $\left(\mathrm{Al}(\mathrm{OH})_{3}\right)$ 였으며, 산을 이용하여 $\mathrm{pH}$ 를 조절한 결과 $\mathrm{pH}$ 가 7 8 영역에서 boehmite 결정상이 얻어졌다. 침전 분말에 남아 있 는 $\mathrm{Na}$ 이온을 제거하고자 세척공정을 진행하여 boehmite 분말을 얻었다. 합성한 분말의 평균입경은 약 $40 \mathrm{~nm}$ 이었다. 또한 열처리 온도가 증가함에 따라 boehmite는 $\gamma-\mathrm{Al}_{2} \mathrm{O}_{3}$ 와 $\delta-\mathrm{Al}_{2} \mathrm{O}_{3}, \theta-\mathrm{Al}_{2} \mathrm{O}_{3}$ 를 거쳐 $\alpha-\mathrm{Al}_{2} \mathrm{O}_{3}$ 결정상으로 상전이가 일어났다.

\section{1. 서 론}

알루미나 $\left(\mathrm{Al}_{2} \mathrm{O}_{3}\right)$ 는 여러 가지 세라믹스 원료 중에서 내열성, 내식성이 우수하고 고강도의 물리적 성질 등을 가지고 있기 때문에, 내마모제, 스파크 플러그, 절연애자, 연마제, 절삭공구, 생체재료, 촉매담체 등 광범위한 용도 로 쓰이고 있다 $[1,2]$. 알루미나 분말은 열처리 온도가 높아짐에 따라 $\gamma$-알루미나, $\delta$-알루미나, $\theta$-알루미나, $\alpha$ 알루미나로 상전이가 일어나며, $\alpha$-알루미나는 높은 강도 를 요하는 구조세라믹 소재로 적합하다[3-6]. 알루미나는 주로 보크사이트(bauxite) 광물을 정제하여 제조(Bayer process)하고 있으며, 분말 크기는 나노미터에서 밀리미 터 크기의 다양한 분말이 개발되고 있다[7-10].

금속 알루미늄은 도로용, 교량용의 가드레일, 건축물,

Corresponding author

Tel: +82-31-645-1431

Fax: +82-31-645-1488

E-mail: kthwang@kicet.re.kr
자동차 부품 등 다양한 분야에 사용되고 있다. 이들 산 업자재로 사용되는 알루미늄은 압출방법을 통해 제조되 는데 압출공정에서 묻어나오는 표면 성분 제거나 표면 산화방지 코팅을 위해 표면을 에칭하게 된다[11, 12]. 가 장 많이 사용하는 에칭물질은 수산화나트륨 $(\mathrm{NaOH})$ 으로 물에 용해하여 용액으로 사용된다. 이 공정에서 에칭된 알루미늄의 농도가 점차 증가하면 에칭속도가 감소하여 에칭액을 폐기하게 된다.

수산화알루미늄은 결정 내부에 포함된 구조수의 양에 따 라 gibbsite, bayerrite와 같은 3수화물, boehmite, diaspore 와 같은 1수화물, 그리고 $\mathrm{Al}_{2} \mathrm{O}_{3} 1 \mathrm{~mole}$ 당 1 mole 이하 의 물 분자를 포함하는 무수화물이 있다[13]. 이 중 1수 화물 형태인 boehmite는 $\gamma-\mathrm{Al}_{2} \mathrm{O}_{3}$ 의 전구체로 촉매담체 에 많이 사용되며, 배기가스 정화촉매와 에틸렌산화물 제조 촉매 등 화학촉매, 그리고 흡착제 및 세라믹 제품 의 전구 물질로 많이 사용되고 있다 $[14,15]$. Boehmite 는 온도가 상승함에 따라 $\gamma-\mathrm{Al}_{2} \mathrm{O}_{3}$ 에서 $\delta-\mathrm{Al}_{2} \mathrm{O}_{3}$ 로 다시 $\theta-\mathrm{Al}_{2} \mathrm{O}_{3}$ 로 그리고 마지막으로 $\alpha-\mathrm{Al}_{2} \mathrm{O}_{3}$ 로 전이하는 것으 
로 알려져 있다[13].

본 논문에서는 폐기되는 에칭용액으로부터 수산화알루 미늄의 하나인 베마이트(boehmite) 분말을 정제하고자 하였다. 합성한 베마이트는 열처리 공정에 의하여 $\gamma$ $\mathrm{Al}_{2} \mathrm{O}_{3}, \alpha-\mathrm{Al}_{2} \mathrm{O}_{3}$ 결정 분말로 상전이 되며, 합성된 분말 들의 특성은 $\mathrm{SEM}$ 및 $\mathrm{XRD}$ 를 통해 조사하였다.

\section{2. 실험방법}

실험에 사용된 폐액은 알루미늄을 $\mathrm{NaOH}$ 용액으로 에 칭한 용액으로 $\mathrm{pH}$ 측정결과 13.5 의 강한 염기성이었다. 우선 실험에 앞서 용액상의 부유물들은 필터링에 의해 분리하였으며 침전반응 시 용액의 온도는 $80^{\circ} \mathrm{C}$ 로 유지 하였다. 침전 반응은 질산 $\left(\mathrm{HNO}_{3}\right)$ 을 첨가하여 각각 반응 시의 $\mathrm{pH}$ 를 $4,7,8,9,12$ 로 바꿔가며 반응시켜 얻어진 침전물을 서로 비교하였다. 가장 많은 boehmite 침전물 을 얻은 $\mathrm{pH}=8$ 조건에 대해 반응시간에 따른 침전물의 양과 $\mathrm{pH}$ 조절에 사용된 산의 양에 따른 침전물의 결정상 을 X-ray diffraction(XRD, D/MAX2500VL/PC, Rigaku Japan)로 동정하였다. 이때 침전된 분말을 증류수에 3 회 세척하여 얻어진 분말에 대해 결정상 분석을 진행하였다.

생성된 boehmite 침전물에 남아있는 $\mathrm{Na}$ 를 세척하기 위해 filter paper가 장착된 vacuum funnel에 투입하고 2 차 증류수를 이용하여 세척을 진행하였다. 필터링하여 분리된 boehmite를 증류수에 넣고 교반한 후 다시 필터 링하는 방법으로 $\mathrm{Na}$ 를 제거하고자 하였고 3회 실시하였 다. 필터링 후 얻어진 분말의 성분을 조사하기 위해 ICP 분석(OES 5300DV, RF power $1300 \mathrm{~W}$ )를 사용하여 성 분을 측정하였다. 이후 건조하여 얻어진 boehmite 분말 에 대해 입도분석기(LA-950V2, HORIBA Corporation, Japan)로 평균입경을 측정하였고, SEM(JSM-6701F, JEOL, Japan)을 통하여 입자의 형상을 관찰하였다. 열처리 시 잔존물의 유무와 결정상변화를 알기 위해 $\mathrm{TGA}(\mathrm{TA}$ instrument, $\mathrm{SDTQ600)}$ 을 이용하여 분당 $10^{\circ} \mathrm{C}$ 의 승온속 도로 $1200^{\circ} \mathrm{C}$ 까지 측정하였다. 얻어진 분말을 각각 700 , $800,900,1000,1100,1200^{\circ} \mathrm{C}$ 열처리하여 결정상의 변 화를 $\mathrm{XRD}$ 로 측정하였다.

\section{3. 결과 및 고찰}

알루미늄 에칭 폐액에서 발생하는 침전물의 결정상을 $\mathrm{XRD}$ 로 분석하여 다음 Fig. 1에 나타내었다. 침전물의 결정상은 알루미늄 수화물인 $\operatorname{gibbsite}\left(\mathrm{Al}(\mathrm{OH})_{3}\right)$ 이었다. 따라서 boehmite 결정상을 얻기 위해서 에칭폐액에 대 해서 후처리가 진행되었다.

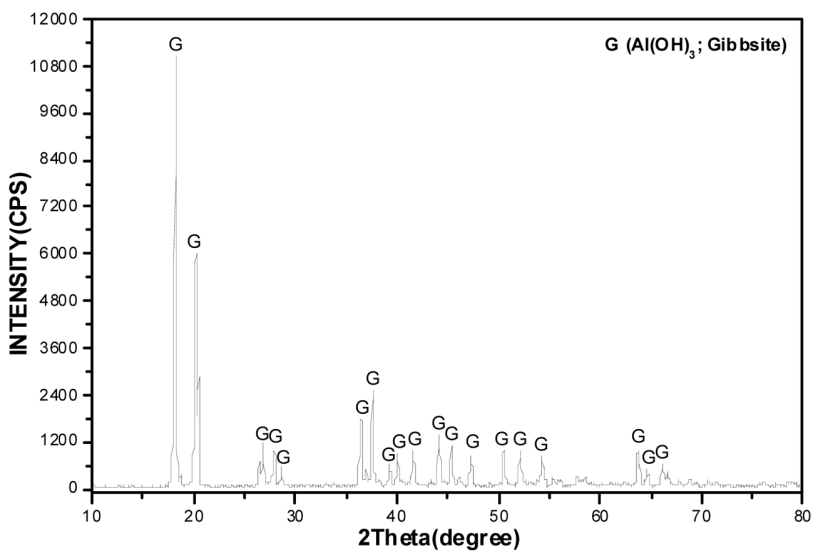

Fig. 1. XRD peak of precipitated powder in aluminum etching solution.

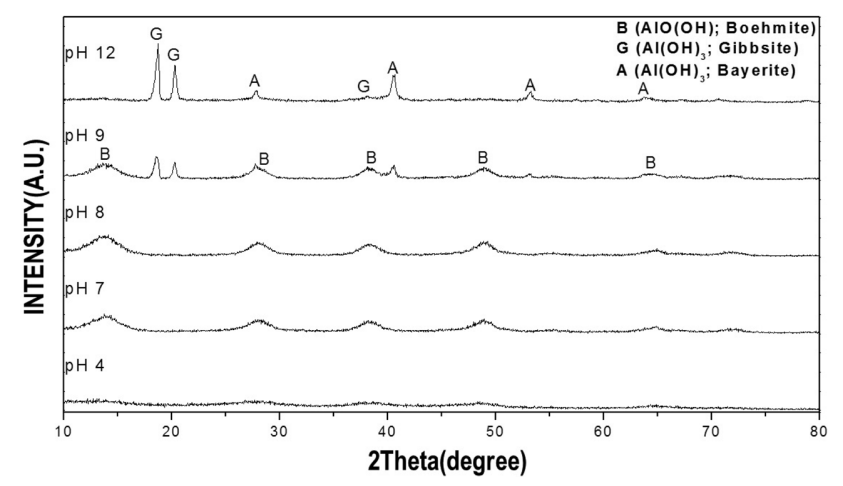

Fig. 2. XRD peaks of dried powders synthesized under different $\mathrm{pH}$ condition.

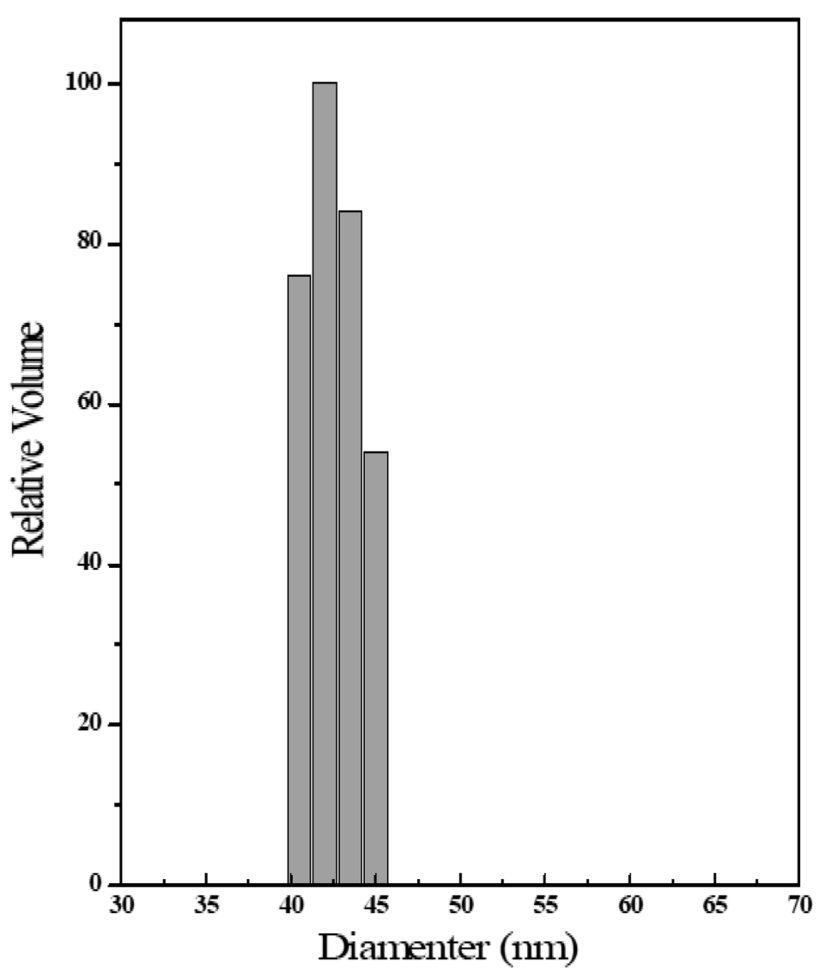

Fig. 3. Particle size of boehmite powder synthesized at $\mathrm{pH}=8$. 
Boehmite 결정상 형성을 위하여 알루미늄 에칭 폐액 의 $\mathrm{pH}$ 를 $\mathrm{HNO}_{3}$ 를 이용하여 조절하였으며, $80^{\circ} \mathrm{C}$ 로 8시 간 교반 후 얻어진 분말의 $\mathrm{pH}$ 농도에 따른 결정상은 Fig. 2 의 XRD에 나타내었다. 첨가한 산에 의해 생성되 는 결정상의 피크를 제거하고자 얻어진 분말을 증류수로 세척하여 분석을 진행하였다. 초기 에칭액 $\mathrm{pH}$ 가 13.5 에 서 산의 첨가에 따라 $\mathrm{pH}$ 가 점점 낮아지면서 $\mathrm{pH}=12$ 에 서는 gibbsite $\left(\mathrm{Al}(\mathrm{OH})_{3}\right)$ 와 bayerite $\left(\mathrm{Al}(\mathrm{OH})_{3}\right)$ 결정상이 나타난다. 산의 첨가량 증가에 따라 이들 결정상의 피크 는 감소하고 $\mathrm{pH}=9$ 에서 boehmite상이 나타나기 시작하 며, $\mathrm{pH}$ 8, 7에서는 boehmite peak만 나타난다. 강산에 가까운 $\mathrm{pH}=4$ 에서는 결정 peak가 보이지 않았으며, boehmite 결정상을 얻기 위한 $\mathrm{pH}$ 는 7 8 범위이었다.

합성한 분말중에서 $\mathrm{pH}=8$ 조건에서 형성된 boehmite 의 입자 크기는 Fig. 3에 나타내었으며 평균입경이 40 $45 \mathrm{~nm}$ 의 크기를 나타내고 있다.

산 첨가에 의해 $\mathrm{pH}$ 조절에 사용된 질산은 $\mathrm{NO}_{3}^{-}$이온 와 $\mathrm{Na}^{+}$이온이 반응하여 $\mathrm{NaNO}_{3}$ 가 생성되어 세척작업이 필요로 하였다. Vacuum funnel과 filter paper를 사용하 여 3번을 반복 세척하였으며 Fig. 4에서 보는 바와 같이 세척 후에는 $\mathrm{XRD}$ 분석에서 $\mathrm{NaNO}_{3}$ 상이 검출이 되지 않았다. 하지만 피크가 검출되지 않을 정도의 소량남아 있을 수 있는 상에 대해서 ICP 분석을 진행 하였다. 세 척이 2번 이루어졌을 때의 $\mathrm{NaNO}_{3}$ 의 양이 $6.57 \%$ 였고 3 번 이루어졌을 때의 $\mathrm{NaNO}_{3}$ 의 양이 $3.40 \%$ 로 줄어들었 다. 세척의 회수를 증가 시키면 $\mathrm{NaNO}_{3}$ 의 양이 거의 줄 어 들 것으로 판단된다. 세척이 완료된 분말을 건조 시 킨 후 얻어진 분말의 SEM 관찰 결과가 Fig. 5 이다. 작 은 입자들이 응집되어 있는 형태이며, 고배율로 확대하 여 보면 나노 크기의 입자들이 응집되어 있는 것을 확인 할 수 있다. $\mathrm{ICP}$ 로 $\mathrm{pH}=8$ 에서 얻이진 침전물을 3 회 세 척한 최종 분체의 성분을 분석한 결과가 Table 1 이다. $\mathrm{SiO}_{2}$ 와 기타 성분들이 각각 $0.1 \mathrm{wt} \%, 0.2 \mathrm{wt} \%$ 이었으며

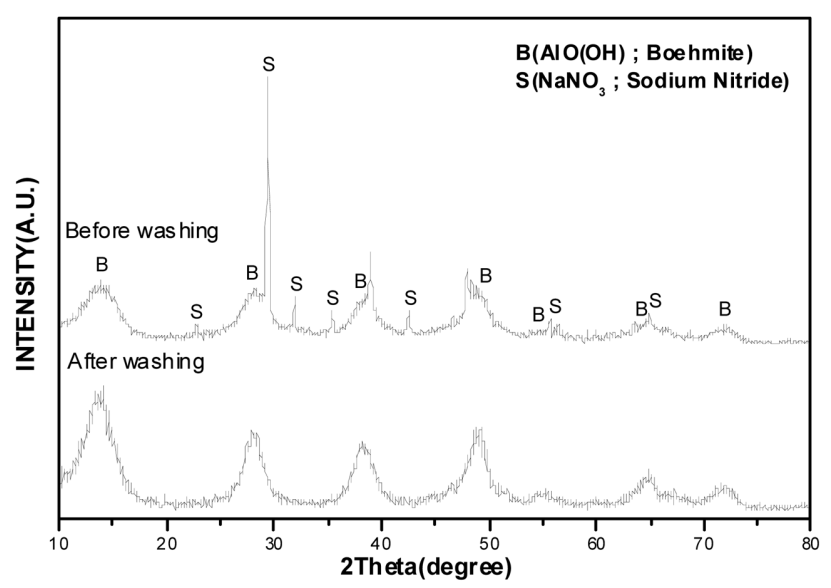

Fig. 4. XRD peaks for as-synthesized powder and washed powder.
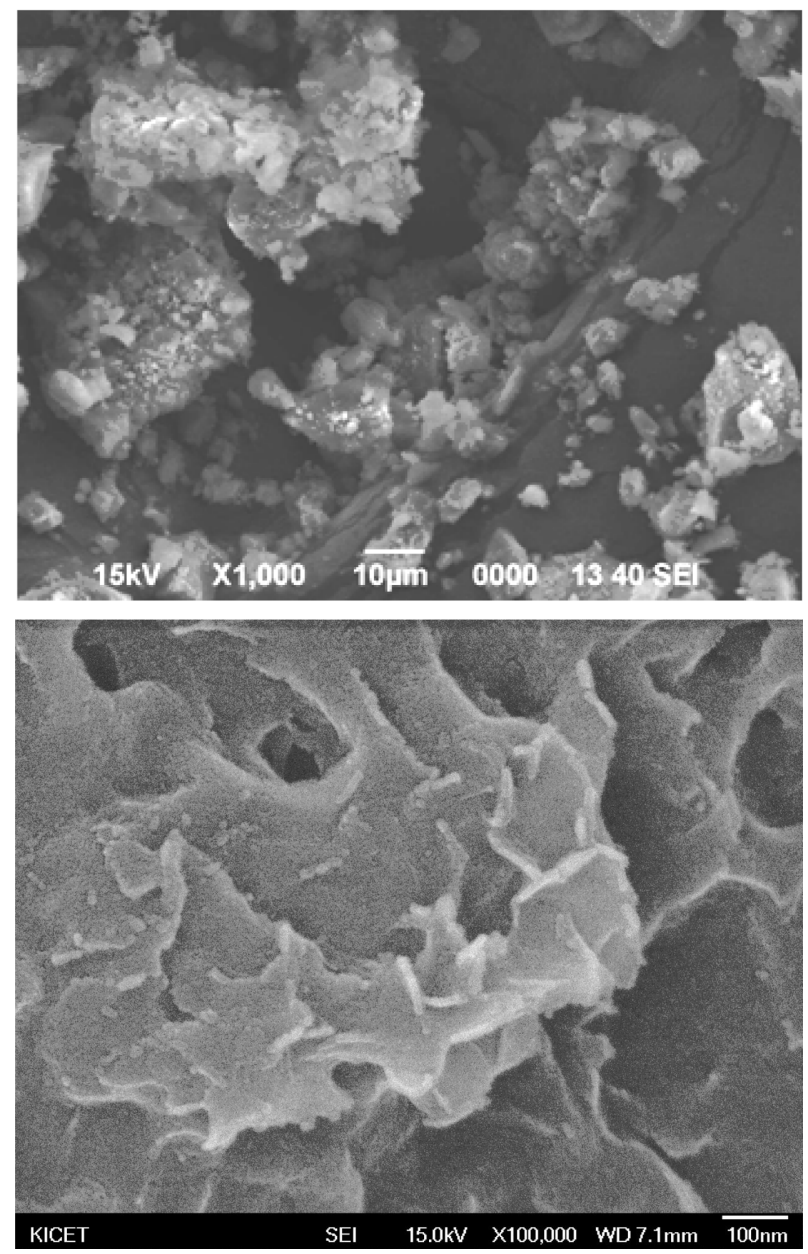

Fig. 5. SEM micrograph of washed boehmite powder.

Table 1

Elemental analysis of boehmite powder by ICP

\begin{tabular}{llllll}
\hline Element & $\mathrm{AlOOH}$ & $\mathrm{NaNO}_{3}$ & $\mathrm{SiO}_{2}$ & Others & Ig. loss \\
\hline Weight $(\%)$ & 68.8 & 3.4 & 0.1 & 0.2 & 27.5 \\
\hline
\end{tabular}

$\mathrm{Na}$ 성분을 제외한 베마이트는 $68.8 \mathrm{wt} \%$ 이었다. 분말 열 처리시 잔존물과 결정상 전이과정을 분석하기 위해 열분 석을 하였으며 그 결과가 Fig. 6이다. $100^{\circ} \mathrm{C}$ 부근에서의 흡열피크는 수분의 건조에 의한 것이며 $450^{\circ} \mathrm{C}$ 부근의 발열피크는 베마이트에서 $\gamma-\mathrm{Al}_{2} \mathrm{O}_{3}$ 의 전이에 기인한 것으 로 판단된다.

건조한 boehmite 분말을 각각의 온도에서 열처리한 분말에 대한 XRD 결정상 분석이 Fig. 7이다. Boehmite 결정상은 $700^{\circ} \mathrm{C}$ 에서 $\gamma-\mathrm{Al}_{2} \mathrm{O}_{3}$ 로 상전이 되었다. 온도가 상승함에 따라 $800^{\circ} \mathrm{C}$ 에서는 $\delta-\mathrm{Al}_{2} \mathrm{O}_{3}$ 가 나타나기 시작하 였으며, $1000^{\circ} \mathrm{C}$ 에서는 $\theta-\mathrm{Al}_{2} \mathrm{O}_{3}$ 상이 나타났다. $\alpha-\mathrm{Al}_{2} \mathrm{O}_{3}$ 결정상은 $1100^{\circ} \mathrm{C}$ 에서 피크가 보이기 시작하여 $1200^{\circ} \mathrm{C}$ 에서는 $\alpha-\mathrm{Al}_{2} \mathrm{O}_{3}$ 결정상만이 나타났다. XRD 피크를 확 대하여 보면 $900^{\circ} \mathrm{C}$ 에서는 $\gamma$ 와 $\delta$ 상이 공존하고 있으며, 


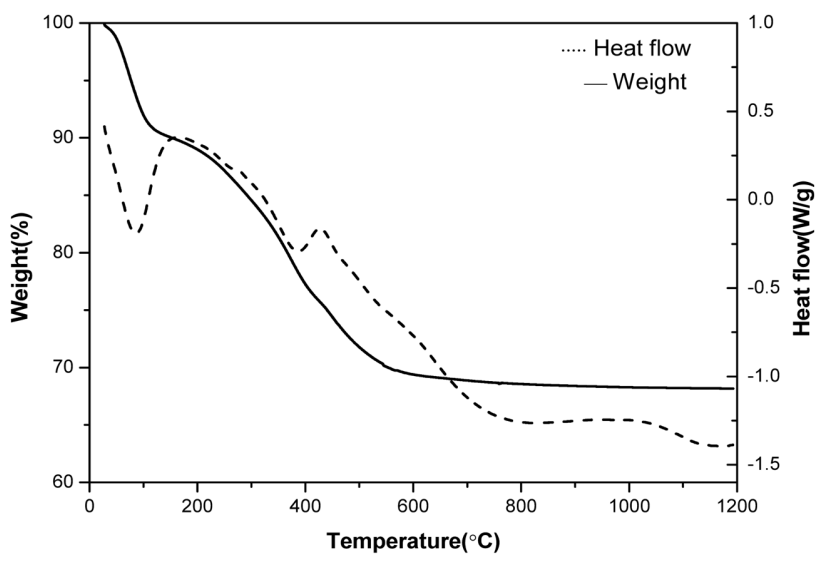

Fig. 6. TG/DTA peak of boehmite powder.

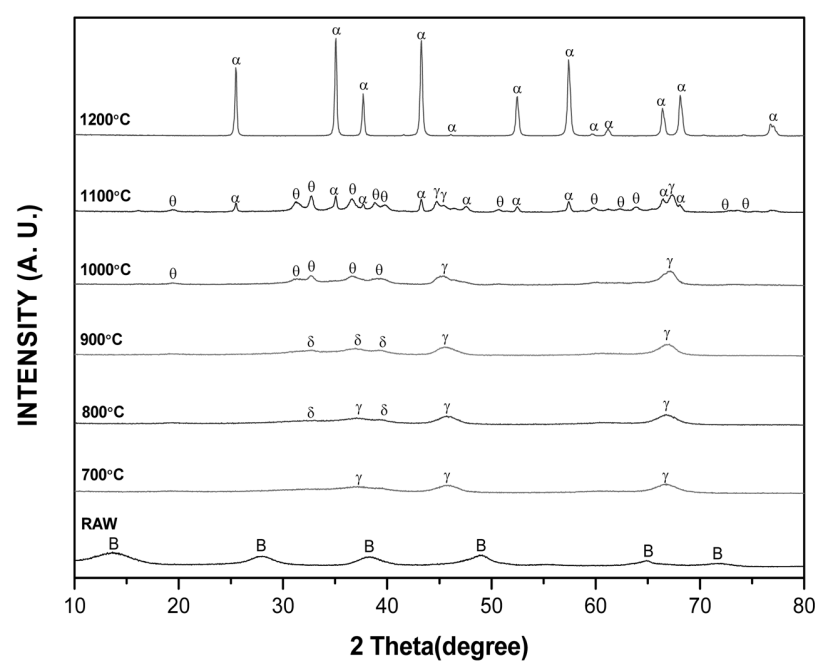

(a)

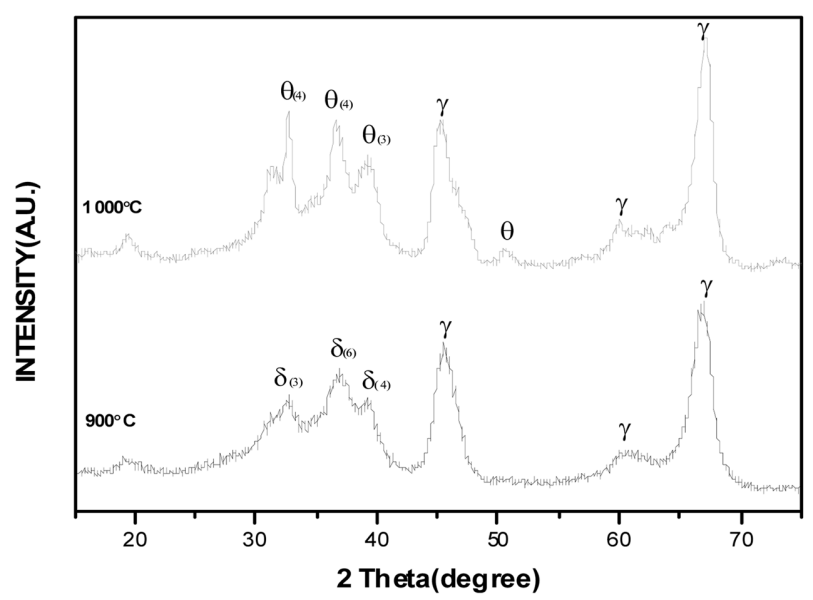

(b)

Fig. 7. XRD peaks of dried and calcined powders: (a) at different temperature and (b) enlarged peaks at $900^{\circ} \mathrm{C}, 1000^{\circ} \mathrm{C}$.

1000 에서는 $\gamma$ 상 피크는 남아 있고 $\delta$ 상이 $\theta-\mathrm{Al}_{2} \mathrm{O}_{3}$ 상으로 상전이 됨을 알 수 있다.

각각의 온도에서 열처리한 분말의 미세구조 관찰결과 는 Fig. 8에 나타내었다. $700^{\circ} \mathrm{C}$ 에서 얻어진 $\gamma-\mathrm{Al}_{2} \mathrm{O}_{3}$ 상

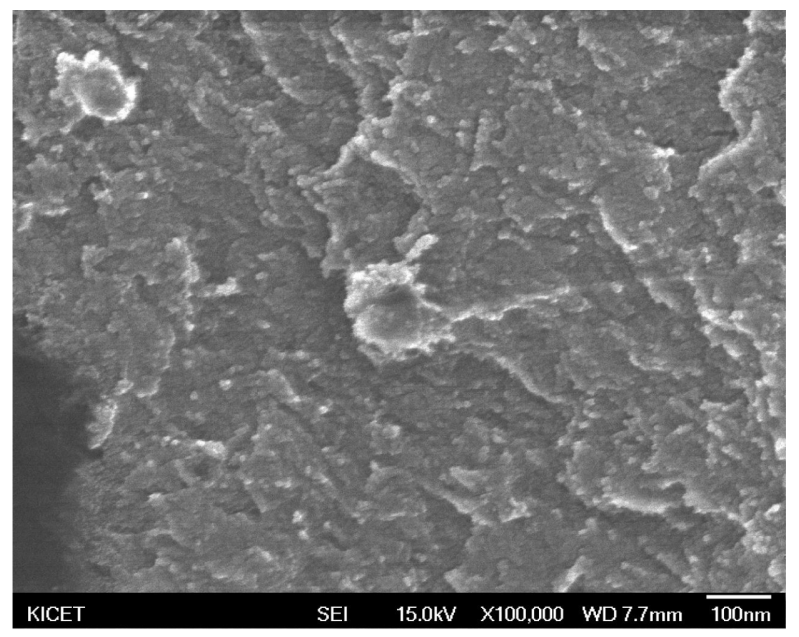

(a)

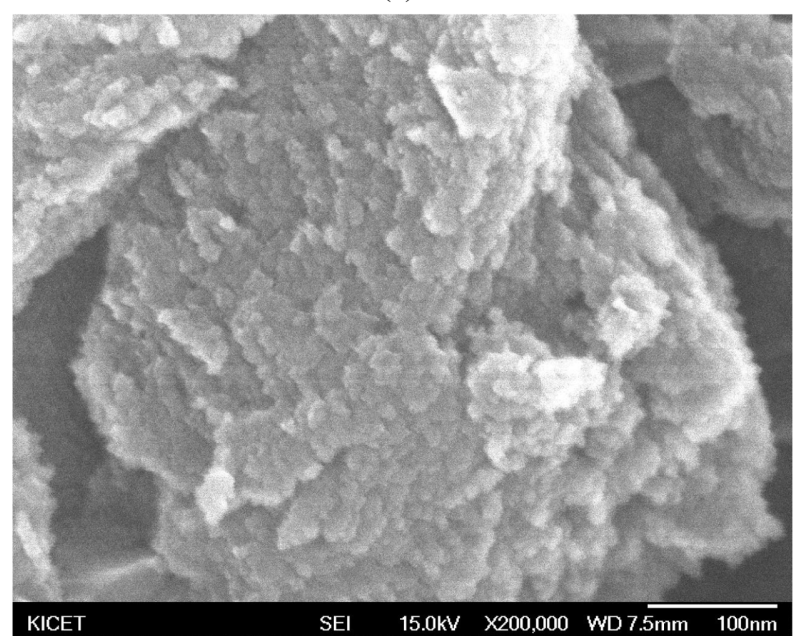

(b)

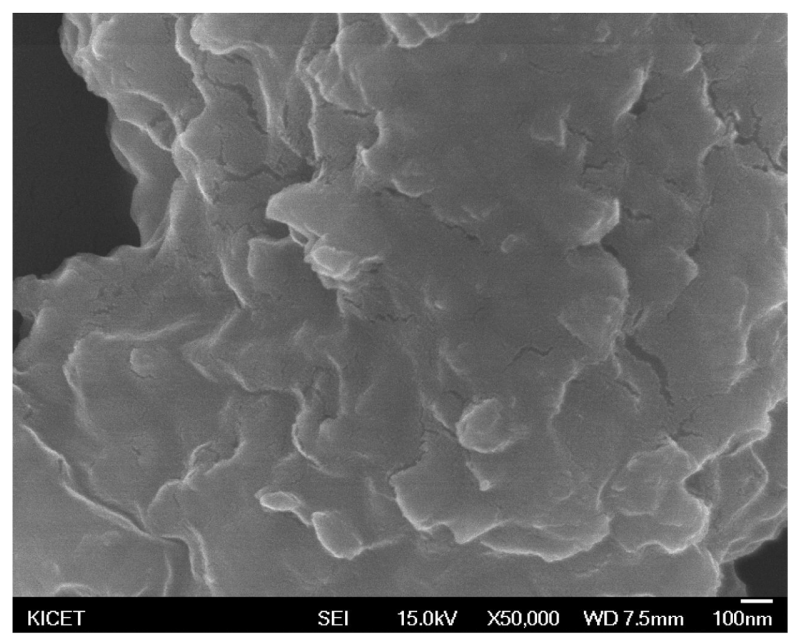

(c)

Fig. 8. SEM micrographs of heat treated powders at (a) $600^{\circ} \mathrm{C}$ ( $\gamma$-alumina), (b) $900^{\circ} \mathrm{C}\left(\delta\right.$-alumina) and (c) $1200^{\circ} \mathrm{C}$ ( $\alpha$-alumina).

은 미세한 분말이 응집되어 있으며, $900^{\circ} \mathrm{C}$ 에서 얻어진 분말의 입자가 커져서 $1200^{\circ} \mathrm{C}$ 에서 열처리한 $\alpha-\mathrm{Al}_{2} \mathrm{O}_{3}$ 결 정상의 입자가 가장 커져 있다. 
열처리 공정을 통해서 출발물질인 boehmite와 촉매로 사용되는 $\gamma-\mathrm{Al}_{2} \mathrm{O}_{3}$ 상이나 알루미나 원료에서 가장 많은 $\alpha-\mathrm{Al}_{2} \mathrm{O}_{3}$ 결정상을 얻을 수 있어 응용에 필요한 결정상 을 얻을 수 있는 조건을 찾을 수 있었다 $[14,15]$. 합성 한 boehmite 분말을 이용하여 알루미나 sol을 합성하거 나 $\gamma-\mathrm{Al}_{2} \mathrm{O}_{3}$ 상을 이용하여 촉매 기능에 대한 연구가 필요 하다[16].

\section{4. 결 론}

알루미늄 에칭공정에서 발생하는 폐액으로부터 정제공 정을 통해 boehmite 분말을 합성하고자 하였다. 폐액에 서 침전되어 있는 결정상은 gibbsite $\left(\mathrm{Al}(\mathrm{OH})_{3}\right)$ 였으며, 산 을 이용하여 $\mathrm{pH}$ 를 조절한 결과 $\mathrm{pH}$ 가 7 8 영역에서 boehmite 결정상이 얻어졌다. 침전 분말에 남아 있는 $\mathrm{Na}$ 이온을 제거하고자 증류수와 종이필터를 이용하여 세척공정을 진행하여 boehmite 분말을 얻었다. 합성한 분말의 평균입경이 약 $40 \mathrm{~nm}$ 의 미세분말로 알루미나 졸 의 출발원료로 사용이 가능할 것이다. 또한 열처리 조건 에 따라 boehmite는 $\gamma-\mathrm{Al}_{2} \mathrm{O}_{3}$ 와 $\alpha-\mathrm{Al}_{2} \mathrm{O}_{3}$ 결정상으로 상 전이가 일어나 촉매나 세라믹스의 원료로 적용이 가능할 것으로 판단된다.

\section{감사의 글}

본 연구는 환경부 "차세대 에코이노베이션사업(글로벌 탑 환경기술개발사업)"의 지원에 의해 수행되었으며 이 에 감사드립니다(과제번호 GT-SWS-11-01-004-0).

\section{참 고 문 헌}

[1] H. Cho and B.W. Lee, "High temperature properties of surface-modified Hastelloy X alloy", Journal of the Korean Crystal Growth and Crystal Technology 22/4 (2012) 183.

[2 2 H.J. Jeong, J.H. Lee and S.J. Boo, "Investigation of aluminium-induced crystallization of amorphous silicon and crystal properties of the silicon film for polycrystalline silicon solar cell fabrication", Journal of the Korean
Crystal Growth and Crystal Technology 20/6 (2010) 254.

[3] B.C. Lippens and J.H. de Boer, "Study of phase transformations during calcination of aluminum hydroxides by selected area electron diffraction", Acta Crystallogr. 17 (1964) 1312.

[4] H.C. Stumpf, A.S. Russell, J.W. Newsome and C.M. Tucker, "Thermal transformations of aluminas and alumina hydrates", Ind. Eng. Chem. 42 (1950) 1398.

[5] G.W. Brindley and I.R. Haya, "Crystallographic aspects of some decomposition and recrystallization reactions", Progress in Ceramic Science Oxford Pergamon Press 3 (1963) p. 3.

[6] R.K. Oberlander, "Aluminas for catalysts: their preparation and properties", Applied Industrial Catalysis 3 Chapter 4, Academic Press (1984) p. 63.

[7] F. Habashi, "Bayer's process for alumina production : A historical perspective", Bull. Hist. Chem $17 / 18$ (1995) 15.

[ 8 ] A. Al Sadi, E. Bonetti, P. Mattioli and G. Valdré, "Internal friction, thermal and structural analysis of nanocrystalline aluminium", J. Alloys Compounds 211-1 (1994) 489.

[9] E. Bonetti, G. Scipione, G. Valdrè, S. Enzo, R. Frattini and P.P. Macrì, "A study of nanocrystalline iron and aluminum metals and fe-al intermetallic by mechanical alloying", J. Mater. Sci. 30 (1995) 2220.

[10] Dariusz Oleszak and Paul H. Shingu, "Nanocrystalline metals prepared by low energy ball milling", J. Appl. Phys. 79 (1996) 2975.

[11] H.H. Jo, S.K. Lee, C.S. Jung and B.M. Kim, "A nonsteady state fe analysis of al tubes hot extrusion by porthole die", J. Mat. Process Tech. 173 (2006) 223.

[12] S.G. Woo and H.R. Lee, "Tungsten wire tip sharpening by electrochemicl etching", J. Kor. Institute of Information Sci. and Eng. 31 (1998) 45.

[13] K. Wefers and C. Misra, "Oxides and Hydroxides of Aluminum", ALCOA Laboratories, Pennsylvania, USA (1987) p. 20.

[14] G. Paglia, C.E. Buckley, A.L. Rohl, R.D. Hart, K. Winter, A.J. Studer, B.A. Hunter and J.V. Hanna, "Boehmite derived $\gamma$-alumina system. 1. Structural evolution with temperature, with the identification and structural determination of a new transition phase, $\gamma$-alumina", Chem. Mater. 16 (2004) 220.

[15] X. Krokidis, P. Raybaud, A.E. Gobichon, B. Rebours, P. Euzen and H. Toulhoat, "Theoretical study of the dehydration process of boehmite to $\gamma$-alumina", J. Phys. Chem. B 105 (2001) 5121.

[16] S.J. Wilson, "The dehydration of boehmite, $\mathrm{AlOOH}$, to $\mathrm{Al}_{2} \mathrm{O}_{3}$ ”, J. Solid State Chem. 30 (1979) 247. 